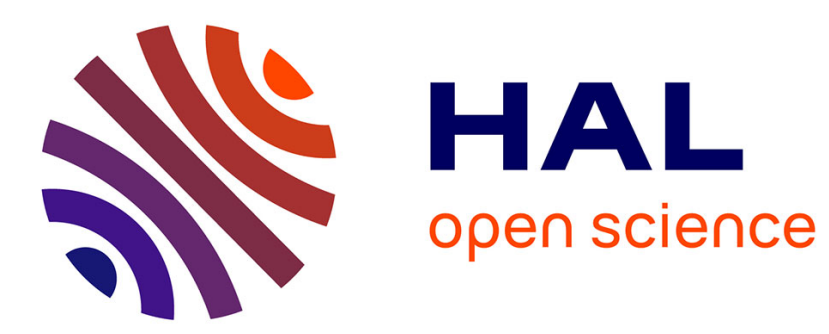

\title{
Managerial Efficiency and Hospitality Industry: the Portuguese Case
}

\author{
Carlos Pestana Barros, Laurent Botti, Nicolas Peypoch, Bernardin \\ Solonandrasana
}

\section{- To cite this version:}

Carlos Pestana Barros, Laurent Botti, Nicolas Peypoch, Bernardin Solonandrasana. Managerial Efficiency and Hospitality Industry: the Portuguese Case. Applied Economics, 2009, pp.1. 10.1080/00036840802600145. hal-00582251

\section{HAL Id: hal-00582251 \\ https://hal.science/hal-00582251}

Submitted on 1 Apr 2011

HAL is a multi-disciplinary open access archive for the deposit and dissemination of scientific research documents, whether they are published or not. The documents may come from teaching and research institutions in France or abroad, or from public or private research centers.
L'archive ouverte pluridisciplinaire HAL, est destinée au dépôt et à la diffusion de documents scientifiques de niveau recherche, publiés ou non, émanant des établissements d'enseignement et de recherche français ou étrangers, des laboratoires publics ou privés. 


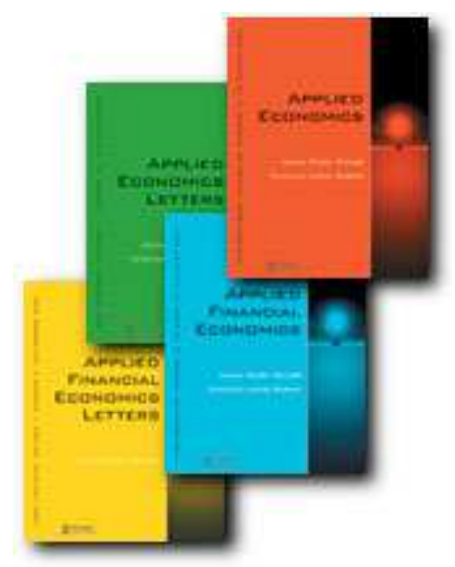

\section{Managerial Efficiency and Hospitality Industry: the Portuguese Case}

\begin{tabular}{|c|c|}
\hline Journal: & Applied Economics \\
\hline Manuscript ID: & APE-07-0422.R1 \\
\hline Journal Selection: & Applied Economics \\
\hline $\begin{array}{l}\text { Date Submitted by the } \\
\text { Author: }\end{array}$ & $31-$ Oct-2008 \\
\hline Complete List of Authors: & $\begin{array}{l}\text { Barros, Carlos; Technical University of Lisbon, ISEG } \\
\text { Botti, Laurent; University of Perpignan, IAE-GEREM } \\
\text { Peypoch, Nicolas; University of Perpignan, IAE-GEREM } \\
\text { Solonandrasana, Bernardin; University of Perpignan, IAE-GEREM }\end{array}$ \\
\hline JEL Code: & $\begin{array}{l}\text { C44 - Statistical Decision Theory|Operations Research < C4 - } \\
\text { Econometric and Statistical Methods: Special Topics < C - } \\
\text { Mathematical and Quantitative Methods, C10 - General < C1 - } \\
\text { Econometric and Statistical Methods: General < C - Mathematical } \\
\text { and Quantitative Methods, C61 - Optimization } \\
\text { Techniques|Programming Models|Dynamic Analysis < C6 - } \\
\text { Mathematical Methods and Programming < C - Mathematical and } \\
\text { Quantitative Methods, D21 - Firm Behavior < D2 - Production and } \\
\text { Organizations < D - Microeconomics, D24 - Production|Capital and } \\
\text { Total Factor Productivity|Capacity < D2 - Production and } \\
\text { Organizations < D - Microeconomics }\end{array}$ \\
\hline Keywords: & $\begin{array}{l}\text { Efficiency, Data envelopment analysis, Bootstrap, Hospitality } \\
\text { industry }\end{array}$ \\
\hline
\end{tabular}




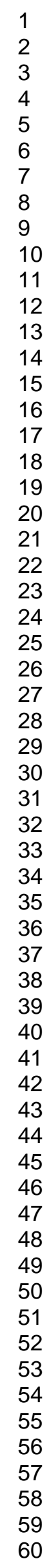

\section{S) ScholaroNE" \\ Manuscript Central}




\title{
Managerial Efficiency and Hospitality Industry: the Portuguese Case* $^{*}$
}

\author{
Carlos Pestana Barros ${ }^{1}$, Laurent Botti ${ }^{23}$, Nicolas Peypoch ${ }^{34}$ and Bernardin \\ Solonandrasana ${ }^{3}$
}

\begin{abstract}
${ }^{1}$ ISEG, Instituto Superior de Economia e Gestao, Technical University of Lisbon, Rua Miguel Lupi, 20, 1249-078 Lisbon, Portugal.

${ }^{2}$ ERFI, Institut des Sciences de l'Entreprise de Montpellier - Université Montpellier I, Espace Richter, Bâtiment B, CS 19519, F - 34960 Montpellier Cedex 2, France.

${ }^{3}$ GEREM, Institut d'Administration des Entreprises, Université de Perpignan Via Domitia, 52 Avenue Paul Alduy, F- 66860 Perpignan Cedex, France.

${ }^{4}$ LAMPS, Faculté des Sciences Exactes et Expérimentales, Université de Perpignan Via Domitia, 52 avenue Paul Alduy, F - 66860 Perpignan Cedex, France.
\end{abstract}

\author{
E-mail : \\ Barros Carlos P (cbarros@iseg.utl.pt) \\ Botti Laurent (laurent.botti@univ-perp.fr). \\ Peypoch Nicolas (peypoch@univ-perp.fr) \\ Solonandrasana Bernardin (solo@univ-perp.fr)
}

\footnotetext{
* Comments by Editor Mark P. Taylor and one anonymous referee of Applied Economics are gratefully acknowledged.
} 


\title{
Managerial Efficiency and Hospitality Industry: the Portuguese Case
}

\begin{abstract}
:
In this paper, the innovative two-stage procedure of Simar and Wilson (2007) is used to estimate the efficiency determinants of Portuguese hotel groups from 1998 to 2005. In the first stage, the hotels' technical efficiency is estimated with DEA in order to establish which hotels have the most efficient performance. These could serve as peers to help improve performance of the least efficient hotels. In the second stage, the Simar and Wilson model is used to bootstrap the DEA scores with a truncated regression.

The paper contributes to the hotel industry literature by adopting a somewhat novel approach that has never been applied to this industry despite its managerial implications. The motivation for the analysis lies in the fact that during the period under analysis Portuguese hotels faced a number of threats. Knowing what the best practices are is then good news for managers and institutions.
\end{abstract}

Keywords: Efficiency, Data envelopment analysis, Bootstrap, Hospitality industry. 


\section{Introduction}

Performance analysis is a central issue of corporate governance because in a competitive environment, a company less efficient than its competitors fails generally to maintain a sufficient market share to survive on the market. The tourism industry is not immune to this performance need. Therefore, developing tools enabling to evaluate the performance of tourism activities is of critical importance. In particular, in order to provide policy makers guidelines, to correct inefficient management directions and to promote positive effects from competition, it proves fundamental to use performance indicators as regard hotels.

Two scientific methods to quantitatively analyse performance are econometric frontier (Kumbhakar and Lovell, 2000) and data envelopment analysis (Cooper, Seiford and Tone, 2000; Thanasoulis, 2001). Both methods have advantages and drawbacks. Unlike the econometric frontier approach, the DEA allows for the use of multiple inputs and outputs, not imposes any functional form on the data, and doesn't make distributional assumptions for the inefficiency term. With DEA, the frontier relates to the sample considered in the analysis i.e. the efficient isoquant is estimated from the data.

This paper analyses the Portuguese hotel industry from 1998 to 2005 with a two-stage DEA procedure to estimate and explain technical efficiency. This technique, developed by Simar and Wilson (2007) overcomes severe limitations inherent in using the two-stage DEA approach commonly employed in the efficiency literature (Balcombe et al., 2008). Following this technique, the efficient DEA scores are calculated in the first stage, and a bootstrap procedure is adopted in the second stage to identify the sources of efficiency. The paper contributes to the hotel industry literature by adopting a quite new model that, despite its managerial implications, has never been applied to this industry.

The motivation for the present research relates to the fact that in spite of the expansion experienced during the period under analysis, Portuguese hotels face a number of threats. Firstly, several financial groups have entered the market. For example, the Portuguese financial institution, Banco Espírito Santo, has recently acquired the Tivoli hotels and expanded it amounting now to fourteen hotels. Secondly, foreign hotel chains have established a market presence, such as HolidayInn and Marriott, taking advantage of the benefits arising from the EU Single Market, which was established in 1992 with the aim of facilitating the free movement of goods 
and services throughout the member-states. Third, much hotel constructions have taken place on the basis of EU funding, which has resulted in the rapid expansion of hotels throughout the country. The combination of all these factors gives to the Portuguese hotel sector an extremely competitive character which points to the need for an improvement in efficiency (Santos, 2004).

This paper is organized as follows: after this now ending introduction, section 2 presents the institutional settings, describing the Portuguese hotel sector and its characteristics; Section 3 reviews the existing literature on the topic; Section 4 explains the theoretical framework; Section 5 exposes the first stage results; Section 6 offers the second stage results; Section 7 discusses the results and considers the limitations of the paper, in addition to possible future research tracks; and Section 8 presents the conclusions.

\section{Institutional Settings}

As a tourist destination, Portugal continues to explore alternatives that would allow for the repositioning of its brand image from a low-cost "sun-and-sand" destination to an international cultural and heritage tourist attraction (Santos, 2004). In response to the efforts of the Portuguese institutional tourist authorities to achieve this repositioning, many new hotels have been built to provide accommodations in "news" regions i.e. not traditionally promoted "sun-and-sand" destinations.

Considering the increased competitiveness in tourism, hotels economic efficiency takes a central importance in the nationwide performance. According to the World Tourism Organisation statistics (1999), Portugal was ranked at the 19th place as a tourist destination in 1990 and at the 24th place in 1998 with $1.1 \%$ of the total amounts of tourists in the world (see the Financial Times Survey on Portugal, 21 October, 2002). This value represents a small value at the international level, especially when it is compared with the value of Portugal neighbour, Spain, 6.7\%. But inbound tourism represents about $5 \%$ of Portuguese national GDP, revealing a significant economic impact of tourism activities which are directly related to the hotel sector.

Similarly to many other countries, the Portuguese hotel sector is comprised of both large and small units that compete in the market. However, a distinct characteristic of the Portuguese hotel sector is that it is dominated by national groups. Specifically, when compared with Spain, which relies extensively on foreign capital, the 
Portuguese hotel sector relies heavily on national capital. For this reason, the country's largest hotel chains mostly comprise national groups. But things are changing with the European common market and we include in our study recognised international names such as Sheraton, Ritz and Savoy.

In Table 1 below, we present several characteristics of the hotels analysed. These hotels outline a representative sample of the most important hotel groups in Portugal. Data, which spans the period from 1998 to 2005, were obtained from the list of the 1000 largest (in terms of sales) enterprises in Portugal which is published annually by a major Portuguese daily newspaper, Diário de Notícias. This publication was supplemented by additional informations obtained from the Portuguese Hotels Association and in the Commercial Company Registry.

We can see that in comparison with other economic entities, the 15 hotels in the sample are small units in economic terms. In the ranking of the largest 1000 Portuguese enterprises, only 5 hotels are present in the top 500. However, Diário de Notícias publishes also the ranking of the largest 1500 enterprises in Portugal and therefore, while some small hotels are not ranked in the 1000 ranking, informations about them can be obtained from the list of the largest 1500. These informations are resumed in the table 2 which presents the institutional settings. Five variables are shown: sales, number of guests, full-time workers, book value of property and operational cost. These variables will serve as outputs and inputs in our study.

- Insert table 1 here -

- Insert table 2 here -

\section{Literature Review}

In this section, we show that this paper makes a fresh contribution to the literature on tourism industry and more precisely to the literature on the hotel sector which is an important and extremely competitive sector in most tourism countries.

First, regarding our subject i.e. hotels performance, previous analysis are restricted to a small number of studies. Among the earliest studies, we cite Brotherton and Mooney (1992), Wejeysinghe (1993), Baker and Riley (1994) and Donaghy (1995) who suggest different methodology but no frontier models to examine the performance of hotels. In Table 3, the latest studies using frontier models to scan the efficiency of tourism organisations are presented.

- Insert table 3 here - 
From a policy perspective, these papers generally propose guidelines to overcome the identified inefficiency. Sometimes, papers discuss hypothesis which say that there is a relation between an organizational or managerial aspect of the enterprise and its efficiency (for example Botti et al., 2009).

When compared with other research fields, this bibliography is, as far as we are concerned, clearly brief for such an important aspect of the tourism industry. Indeed, tourism is vital for many countries such as Thailand, Morocco or Fiji (Narayan, 2005). This is due to the large intake of money for domestic businesses and to the opportunity for employment in the service industries associated with tourism, i.e. transportation services such as taxis, accommodation such as hotels, and other hospitality industry services such as resorts. With the present paper, we seek to call the attention of management researchers to this neglected aspect of one of the fastest growing industries in the world (Bhattacharya and Narayan, 2005).

Moreover, we can see that there is only one study that use a two stage procedure; and that the paper of Barros and Dieke (2007) use the Malmquist nonparametric technique, which is calculated from DEA linear programming approach and which enables separation of the catching-up effect, i.e. changes over time in technical efficiency, from technological change, i.e. the shift, due to technological progress, of the best practice frontier over time. Then our paper is innovative from this methodological perspective as it employs the DEA Simar and Wilson (2007) technique to estimate and explain technical efficiency of hotels.

\section{Theoretical Framework}

Our framework is based on two literature streams: models of industry efficiency and data envelopment analysis.

\subsection{Models of Industry Efficiency}

Most studies on tourism efficiency are empirically driven, with no clear theoretical framework. On the contrary, in this paper, two economic efficiency models are adopted as theoretical reference. Firstly, the strategic-group theory (Caves and Porter, 1977) which justifies differences in efficiency scores as being due to differences in the structural characteristics of units within an industry, which in turn lead to differences in performance. Units with similar asset configurations pursue similar strategies with similar results in terms of performance (Porter, 1979). While there are 
different strategic options to be found in an industry, due to mobility impediments, not all options are available to each organization in the industry, causing a spread in their efficiency score. Secondly, the resource-based theory (Barney, 1986, 1991; Rumelt, 1991; Wernerfelt, 1984) that justifies different efficiency scores by the fact that organizations base their strategy on resources and competences that don't have the same quality and that are not perfectly mobile across the industry.

Purchasable assets cannot be considered to represent sources of sustainable profits. Indeed, critical resources are not available in the market. Rather, they are built up and accumulated by the organisation, their non-imitability and non-substitutability being dependent on the specific traits of their accumulation process. Differences in resources thus result in barriers to imitation (Rumelt, 1991) and in managers' ability to preserve accumulated critical resources over time. In this context, assets exhibit inherently differentiated levels of efficiency and sustainable profits are ultimately a return on the unique assets controlled by the organisation (Teece et al., 1997).

\subsection{Methodology}

Following Farrell (1957), Charnes et al. (1978) first introduced the term, data envelopment analysis to describe a mathematical programming approach to the construction of production frontiers and the measurement of efficiency in relation to the constructed frontiers. At this time, a large number of articles on theoretical extensions and empirical applications of DEA have been published. Surveys of these papers can be found in Lovell and Schmidt (1988), Lovell (1993) and Tavares (2002).

\section{Estimation of Efficiency Scores}

To estimate efficiency scores for each observation, we use a DEA estimator. The DEA approach usually (but not always) assumes that all firms, or more broadly, decision-making units (DMUs) within a sample have access to the same technology for transforming a vector of $N$ inputs, denoted with $x$, into a vector of $M$ outputs, denoted with $y$. We assume that technology can be characterised by the technology set, $T$, defined as ${ }^{\dagger}$ :

$$
T=\left\{(x, y) \in \mathfrak{R}_{+}^{N} \times \mathfrak{R}_{+}^{M} \quad: \quad x \in \mathfrak{R}_{+}^{N} \quad \text { can produce } y \in \mathfrak{R}_{+}^{M}\right\} .
$$

\footnotetext{
${ }^{\dagger}$ We assume that standard regularity conditions of the neo-classical production theory hold (for details, see Färe and Primont (1995)).
} 
Having access to the same technology, any of the DMUs may or may not be on the frontier of this technology; the distance of a particular DMU from the frontier may depend on various factors which may be endogenous to the DMU, such as the organisational form and/or exogenous, such as the competitive rivalry or government policies. The distance from the actual allocation of each DMU in technology set $T$ to the frontier of $T$ is believed to represent the inefficiency of each DMU and is caused by the DMU's specific endogenous or exogenous factors and some unexplained statistical noise. Our goal is to measure such inefficiency and investigate its dependency on drivers of efficiency.

Our analysis will follow a two-stage approach and in this sub-section, we focus on the first stage, where we estimate efficiency scores for each DMU $j(j=1, \ldots, n)$, using the Farrell/Debreu-type output-oriented technical efficiency measure:

$$
\operatorname{TE}\left(x^{j}, y^{j}\right)=\max _{\theta}\left\{\theta \quad: \quad\left(x^{j}, \theta y^{j}\right) \in T\right\} .
$$

In practice, $T$ is unobserved and so we replace it with its DEA-estimate, $\hat{T}$ :

$$
\begin{gathered}
\hat{T}=\left\{(x, y) \in \mathfrak{R}_{+}^{N} \times \mathfrak{R}_{+}^{M}: \sum_{k=1}^{n} z_{k} y_{m}^{k} \geq y_{m}, m=1, \ldots, M, \sum_{k=1}^{n} z_{k} x_{i}^{k} \leq x_{i},\right. \\
\left.i=1, \ldots, N, z_{k} \geq 0, k=1, \ldots, n\right\} .
\end{gathered}
$$

where $z_{k} \geq 0 \quad(k=1, \ldots, n)$ are the intensity variables over which optimisation (2) is made. Geometrically, $\hat{T}$ is the smallest convex free disposal cone (in $(x, y)$-space) that contains (or 'envelopes') the input-output data". It is a consistent estimator of the unobserved true technology set $T$, under the assumption of constant returns to scale $(\mathrm{CRS})^{\S, * *}$.

\footnotetext{
For more details on DEA, see Fare, Grosskopf and Lovel (1994), Charnes et al. (1995), Briec (1997), Coelli, Prasada and Battese (1998), Copper et al. (2000) and Thanassoulis (2001).

$\S$ Alternatively, the non-increasing returns to scale (NIRS) or variable returns to scale (VRS) would be modelled if the constraint $\sum_{k=1}^{n} z_{k} \leq 1$ or $\sum_{k=1}^{n} z_{k}=1$, respectively, is added to (3). In this paper we assume CRS to gain more discriminatory power in comparison between DMUs and then analyse the returns-to-scale component in the second stage.

** The proof of consistency also requires certain regularity conditions (see Kneip et al. $(1998,2003)$ for these conditions, the resulting rates of convergence, the limiting distribution of DEA estimators, etc.)
} 
The estimates of the efficiency scores, $T \hat{E}_{j}(j=1, \ldots, n)$, obtained by replacing $T$ with $\hat{T}$ in (2) are consistent estimates of the corresponding true efficiency scores, $T E_{j}(j=1, \ldots, n)$ given by (2). They are bounded between unity and infinity, with unity representing an estimated perfect (technical or technological) efficiency score of $100 \%$. On the other hand, $\left(1 / T \hat{E}_{j}\right)$ would represent the estimated relative \%-level of the efficiency of the $j^{\text {th }}$ DMU $(j=1, \ldots, n)$, relative to the estimated best-practice technology frontier, $\hat{T}$.

In our study, we measure outputs by

(i) sales,

(ii) number of guests,

and inputs by

(iii) full-time workers,

(iv) book value of property,

(v) operational costs.

\section{Regression Analysis of Determinants of Efficiency}

Next, we briefly outline an application of regression analysis for studying dependency between the efficiency scores and hypothesised explanatory variables, following the approach of Simar and Wilson (2007). Here, we assume and test the following specification:

$$
T E_{j}=a+Z_{j} \delta+\varepsilon_{j}, \quad j=1, \ldots, n
$$

which can be understood as the first-order approximation of the unknown true relationship. In equation (4), $a$ is the constant term, $\varepsilon_{j}$ is statistical noise, and $Z_{j}$ is a (row) vector of observation-specific variables for DMU $j$ that we expect is related to the DMU's efficiency score, $T E_{j}$, through the vector of parameters $\delta$ (common for all $j$ ) that we need to estimate.

\footnotetext{
** These properties include various forms of continuity, (weak) monotonicity, commensurability, homogeneity and (weak) indication for all technologies satisfying certain regularity conditions (see Russell (1990, 1997) for details).
} 
A common practice in the DEA literature for estimating model (4) had previously been to employ the Tobit-estimator, until Simar and Wilson (2007) demonstrated that such an approach is inappropriate. Instead, they justify an approach based on a truncated-regression with a bootstrap, and illustrate (in Monte Carlo experiments) its satisfactory performance. Here, we will employ their approach. Specifically, noting that the distribution of $\varepsilon_{j}$ is restricted by the condition $\varepsilon_{j} \geq 1-a-Z_{j} \delta$ (since both sides of (4) are bounded by unity), we follow Simar and Wilson (2007) and assume that this distribution is truncated normal with zero mean (before truncation), unknown variance, and (left) truncation point determined by this very condition. Furthermore, we replace the true but unobserved regressand in (4), TE $E_{j}$, by its DEA estimate $T \hat{E}_{j}$. Formally, our econometric model is given by:

$$
T \hat{E}_{j} \approx a+Z_{j} \delta+\varepsilon_{j}, \quad j=1, \ldots, n,
$$

where

$$
\varepsilon_{j} \sim N\left(0, \sigma_{\varepsilon}^{2}\right), \text { such that } \quad \varepsilon_{j} \geq 1-a-Z_{j} \delta, j=1, \ldots, n,
$$

which we estimate by maximising the corresponding likelihood function, with respect to $\left(\delta, \sigma_{\varepsilon}^{2}\right)$, given our data. Relying on asymptotic theory, normal tables can be used to construct confidence intervals but more precision can be gained by using the bootstrap, particularly because our regressand are not true variables, but their estimates that are likely to be dependent (see Simar and Wilson (2007) for details). To construct the bootstrap confidence intervals for the estimates of parameters $\left(\delta, \sigma_{\varepsilon}^{2}\right)$, we use the parametric bootstrap for regression, which incorporates information on the parametric structure and distributional assumption. For the sake of brevity, we refer the reader to Simar and Wilson (2007) for the details of the estimation algorithm.

\section{DEA Results}

When one talks about the efficiency of a firm, one usually means its success in producing as large as possible an output from a given set of inputs. Our paper adopts this direction and will therefore estmates an output-oriented technically efficient (TE) DEA index, assuming that hotels aim to maximize the profits resulting from their activity.

As far as models are concerned, the CCR (or Charnes, Cooper and Rhodes) efficient score model (1978) is probably the most widely used and best known DEA model. It 
is the DEA model that assumes constant returns to scale relationship between inputs and outputs. CCR measures the overall efficiency for each unit, namely in aggregating pure technical efficiency and scale efficiency into one value (Gollani and Roll, 1989). The BCC (or Banker, Charnes and Cooper) efficient score model (1984) is a DEA model that assumes variable returns to scale between inputs and outputs. It measures pure technical efficiency alone (Gollani and Roll, 1989). The efficiency score obtained with the BCC model gives a score which is at least equal to the score obtained using the CCR. Scale efficiency score is obtained by dividing the aggregated CCR score by the technical efficient BCC score (Färe et al, 1994). A unit is scale efficient when its size of operation is optimal. If its size is either reduced or increased, its efficiency will drop.

The choice of an assumption about returns-to-scale (constant versus variable) is not neutral because it conditions the representation of the possibility set. The assumption of constant returns to scale implies a long term vision where units' size can be modified. With the variable returns-to-scale assumption, the reasoning takes place in the short run and units' size is fixed. In our case, since hotel chains have different size (according to their total number of hotels) and their scale size is controllable by their central management, the variable return-to-scale hypothesis was chosen. Moreover, the VRS score measures pure technical efficiency only; then, when assuming that pure technical efficiency is attributed to managerial skills, the BCC scores are interpreted as managerial skills.

However, for comparative purposes, we also present the constant returns-to-scale index which is composed of a non-additive combination of pure technical and scale efficiencies. A ratio of the overall efficiency score (the CRS score) to pure technical efficiency score (the VRS score) provides a scale efficiency measurement. The CRS, VRS and scale efficiency scores of the analysed hotels are presented in Table 4. The ranking in Table 4 is in hierarchical order of VRS technical efficiency scores, starting from the most efficient to the least efficient.

- Insert table 4 here -

A number of points emerge from the present study. Firstly, similar to previous research on hotels (Reynolds, 2003), significant differences in efficiency are prevalent among Portuguese hotels. The DEA score is between zero (0\%) and 1 (100\%). Units with DEA scores equal to $1(100 \%)$ are efficient. A unit with a score of less than $100 \%$ is relatively inefficient, e.g. a unit with a score of $95 \%$ is only $95 \%$ as efficient 
as the best performing hotels. Secondly, best-practice calculations indicate that almost all Portuguese hotels operate at a high level of technical efficiency during the period. Thirdly, all technically efficient CRS hotels are also technically efficient in VRS, signifying that the dominant source of efficiency is scale. Fourthly, the efficiency scores presented in Table 4 are average values for the period, but when the hotels are analyzed across all years, the result is the same: most Portuguese hotels display technical efficiency, but some of them do not display scale efficiency. Therefore, the overall conclusion is that Portuguese hotels are well managed as far as technical efficiency is concerned. However, dimension makes a difference and therefore, some hotels have decreasing returns to scale (DRS), while others have increasing returns to scale (IRS). Hotels with DRS are too large in dimension and should be decreased. Hotels with IRS are too small in dimension and should be increased.

\section{Determinants of Efficiency}

In order to examine the hypothesis that the efficiency of the Portuguese hotel companies is determined by different contextual variables, we followed the two-step approach, as suggested by Coelli et al. (1998), estimating the regression shown below. It is recognised in the DEA literature that the efficiency scores obtained in the first stage are correlated with the explanatory variables used in the second term, and that the second stage estimates will then be inconsistent and biased (Simar and Wilson, 2000). A bootstrap procedure is needed to overcome this problem (Efron, 1979; Efron and Tibshirani, 1993). To this end, as explained earlier, we adopt the approach of Simar and Wilson (2007).

The estimated specification is the following:

$$
\begin{aligned}
& \theta_{i, t}=\beta_{0}+\beta_{1} \text { Trend }_{i, t}+\beta_{2} . \text { Trend }_{i, t}^{2}+\beta_{3} . \text {.uoted }_{i, t}+\beta_{4} M \& A_{i, t}+ \\
& \beta_{5} \text { Group }_{i, t}+\beta_{6} \text { International }_{i, t}+\varepsilon_{i, t}
\end{aligned}
$$

where $\theta$ represents the CCR efficient score. Trend is a yearly trend. Square trend is the square value of the trend. Quoted is a dummy variable which is one for quoted hotel groups and zero otherwise. This aims to capture the efficiency related to the scrutiny inherent in being quoted on the stock market. $M \& A$ is a dummy variable which is one for companies involved in mergers and acquisitions and zero otherwise. This aims to capture growth orientation strategies inherent in some hotel groups. Group is a dummy variable which is one for hotels belonging to an economic group, 
and zero otherwise. It aims to capture economies of scope in the activity. Finally, International is a dummy which is one for hotel groups with an international expansion strategy. It aims to capture international growth orientation strategies.

For comparative purpose the traditional Tobit model has been estimated with bootstrap and results revealed that while the signs of the parameters are maintained, their values changed a lot, namely the value of the variance, meaning that the Simar and Wilson (2007) procedure is more efficient.

\section{- Insert table 5 here -}

The truncated regression with a bootstrap model appears to fit the data well, with positive t-statistics, which are statistically significant for all parameters, with the exception of the international dummy variable.

It is observed that the efficiency increases over the observation period, according to the trend, but at decreasing rates, according to the square term. A rationale for this is based on the growth limits of internal markets. Quotation contributes to the efficiency. This means that the discipline of the stock exchange and the public scrutiny inherent to it contribute to the efficiency of the hotels. To be involved in mergers and acquisitions contributes to efficiency. This is an expected result, since companies involved in $M \& A s$ are more aware of their market environment. They must also be aware of their efficiency. To be a member of a hotel group also contributes positively to the efficiency, since it induces internal benchmarking which contributes to efficiency improvements. Finally, to be involved in an international expansion strategy increases the efficiency. A rationale for this is based on the awareness that must accompany such a strategy and which naturally translates into efficiency increases.

\section{Discussion, Limitations and Extensions}

What is the explanation for such dispersion of the efficiency scores among Portuguese hotels? The first reason is the economics of scope, related to activities such as casinos in some hotels, as for example in the Estoril Sol and the Solverde. The second reason is dimension due to scale economies, present in Vila Galé and M.\&J. Pestana. The third possible reason is bad management, since it is recognised that the Portuguese management continues to suffer from various weaknesses. Evidence of managerial inefficiency was identified in an exhaustive survey on Portuguese management jointly conducted by AdCapita and Cranfield University (available in www.adcapita.com). 
The fourth reason is derived from the complacency of the Portuguese tourist enterprises relative to foreign capital. This closeness is a distinctive characteristic of the Portuguese tourism industry, when compared with its Spanish counterpart, and was recently supported by European funding of Portuguese hotel constructions. The closeness appears to induce indolence in the managerial behaviour. Fifth and finally, these enterprises usually nurture close links with the government, which is beneficial for gaining access to European subsidies and manifested in the fact that it is not unusual to find former senior civil servants occupying directorial positions on the boards of the hotel enterprises. Associated to other reasons, such cronyism results in bad management. Reasons related to the economic environment, such as the VAT rate, are not taken into account in this paper.

The findings of the empirical study show that there are several drivers of efficiency in Portuguese hotels. These drivers comprise the facts of being quoted on the stock market, adopting $M \& A$ strategies and being part of a group. It is important to take these elements into consideration when crafting a new strategy in order to improve corporate efficiency.

What is the innovation in the present research? First, the true efficiency score $\theta$ estimated in first stage is not observed directly but is empirically estimated. Thus, the usual estimation procedures that assumes independently distribute error terms are not valid. Second, the empirical estimates of frontier efficiency are calculated based on the sample of hotels used, which excludes some efficiency production possibilities that are feasible but not observed in the sample. This implies that the empirical estimates of efficiency are upwardly biased (Simar and Wilson, 2007). Thirdly, the two stage procedure also depends upon other explanatory variables, which are not taken into account in the first stage efficiency estimation. This implies that the error term must be correlated with the second stage explanatory variables. Fourthly, the domain of the efficient score $\theta$ is restricted to the interval zero and one, which should be taken into account in the second-stage estimation (Simar and Wilson, 2007). Overall, Simar and Wilson (2007) propose a procedure to deal with these challenges, based on a double bootstrap that enables consistent inference within models explaining efficiency scores while simultaneously producing standard errors and confident intervals for these efficiency scores. For example, an alternative bootstrap procedure adopted by Xue and Harker (1999) has been shown to be inconsistent by 
Simar and Wilson (1999). Related to the functional specification, it is recognized that the Tobit does not describe adequately the efficient scores. The truncated bootstrapped second-stage regression proposed by Simar and Wilson (2007) better describes the efficient scores.

Thus, the contribution of this paper to the literature with respect to technique is threefold:

(i) it improves the existing methods using DEA, by comparing and contrasting relative approaches and variations;

(ii) it combines DEA technique with a recently developed method; in using this method to bootstrap the DEA scores with a truncated regression, it better (from an econometric viewpoint) explains DEA efficiency levels;

(iii) it presents the broader relevance of this new procedure which offers some improvements in both estimation quality and inference in the second stage. Indeed, by adopting the functional form (or truncated functional form) in the second stage, it has enabled consistent inference to explain efficiency scores while simultaneously producing standard errors and confidence intervals for these efficiency scores.

Furthermore, the paper has also provided benchmarks for improving operations of hotels that perform poorly, arguing that quoted and $M \& A$ parameters increase efficiency. However, more research is needed to confirm these results. Indeed, the principal limitation of the paper is related to the data used. The homogeneity of the sample is questionable, since we compare companies with different dimensions and production characteristics. They may face different restrictions and therefore, might not be considered to be directly comparable. However, we can always claim that the units are not comparable and then a ratio analysis could not equally be carried out. Moreover, the data set is short, thus the conclusions are limited. In order to generalise them, we would need to have a larger data set. Indeed, reducing the number of observations in a DEA procedure increases the likelihood that a given observation is judged relatively efficient (Banker, 1993).

Several research tracks can be proposed. First, in this analysis, the DEA model allowed for complete weight flexibility. In situations in which some of the measures are likely to be more important than others, DEA allows for restricting factor weights through linear constraints. These linear constraints represent ranges for relative preferences among factors based on managerial input. Such analysis enables effective 
incorporation of managerial input into the DEA evaluations. Second, the input and output dimensions considered are context-specific. More comprehensive input and output measurements, namely, allowing for non-discretionary factors, such as environmental, socio-economic or quality inputs and outputs, need to be taken into consideration. The influence of non-discretionary variables, excluded from our analysis, amounts to an assumption that these factors are constant across the sample. Third, non-parametric, or alternatively, parametric free-disposal hull analysis can be used to assess the efficiency scores. However, previous research has shown that although the DEA scores are inferior in value to econometric scores, the ranking is preserved (Bauer et al., 1998).

\section{Conclusion}

This article proposed a simple framework for the evaluation of Portuguese hotels and the rationalisation of their operational activities. The analysis was based on a DEA model that allowed for the incorporation of multiple inputs and outputs in determining the relative efficiencies. Benchmarks were provided in order to improve the operations of the less performing companies. In the second stage, the determinants of the economic efficiency were investigated. Several interesting and useful managerial insights and implications from the study were discussed.

The general conclusion is that the hotel companies should adopt procedures that induce greater efficiency, in following the example of efficient peers identified in the benchmarking exercise. However, more investigations are needed to confirm these first results and clarify unresolved questions. 


\section{References}

Anderson, R.I., Lewis, D. and Parker, M.E. (1999), Another Look at the Efficiency of Corporate Travel Management Departments, Journal of Travel Research, 37(3): 267-272.

Anderson, R.I., Fish, M., Xia, Y. and Michello, F. (1999), Measuring Efficiency in the Hotel Industry: A Stochastic Frontier Approach, International Journal of Hospitality Management, 18(1): 45-57.

Anderson, R.I., Fok, R. and Scott, J. (2000), Hotel Industry Efficiency: An Advanced Linear Programming Examination, American Business Review, 18(1): 4048.

Balcombre, K., Fraser, I., Latruffe, L., Rahman, M. and Smith, L. (2008), An Application of the DEA Double Bootstrap to Examine Sources of Efficiency in Bangladesh Rice Farming, Applied Economics, 40(15): 19191925.

Banker, R.D. (1993), Maximum Likelihood, Consistency and Data Envelopment Analysis, Management Science, 39(10): 1265-1273.

Baker, M. and Riley, M. (1994), New Perspectives on Productivity in Hotels: Some Advances and New Directions, International Journal of Hospitality Management, 13(4): 297-311.

Barney, J. (1986), Strategic Factor Markets: Expectations, Luck and Business Strategy, Management Science, 32: 1231-1241.

Barney, J. (1991), Firm Resources and Sustained Competitive Advantage, Journal of Management, 17: 99-120.

Barros, C.P. (2005), Evaluating the Efficiency of a Small Hotel Chain with a Malmquist Produtivity Index, International Journal of Tourism Research, 7: $173-184$.

Barros, C.P., and Alves, P. (2004), Productivity in Tourism Industry, International Advances in Economic Research, 10(3): 215- 225.

Barros, C.P. and Dieke, P.U.C. (2007), Analyzing the Total Productivity Change in Travel Agencies, Tourism Analysis, 12(3/4).

Barros, C.P. and Santos, C. (2006), The Measurement of Efficiency in Portuguese Hotels using Data Envelopment Analysis, Journal of Hospitality and Tourism Research, 30(3): 378-400.

Bauer, P.W. Berger, A.N., Ferrier, G. and Humphrey, D.B. (1998), Consistency Conditions for Regulatory Analysis of Financial Institutions: A Comparison of Frontier Methods, Journal of Economics and Business, 50: 85-114.

Bell, R.A. and Morey, R.C. (1995), Increasing the Efficiency of Corporate Travel Management through Macro-Benchmarking, Journal of Travel Research, 33(3): 11-20.

Bhattacharya, M. and Narayan, P.K. (2005), Testing for the random Walk Hypothesis in the Case of Visitor Arrivals: Evidence from Indian Tourism, Applied Economics, 37: 1485-1490.

Botti., L., Briec, W. and Cliquet, G. (2009), Plural Forms versus Franchise and Company-Owned Systems: A DEA approach of Hotel Chain Perforamnce, Omega, 37: 566-578.

Briec, W. (1997), A Graph-type Extension of Farrell Technical Efficiency Measure, Journal of Productivity Analysis, 8(1):95-110. 
Brown, J.R. and Ragsdale, C.T. (2002), The Competitive Market Efficiency of Hotel Brands: An application of Data Envelopment Analysis, Journal of Hospitality \& Tourism Research, 26(4): 332-260.

Brotherton, B. and Mooney, S. (1992), Yield Management Progress and Prospects, International Journal of Hospitality Management, 11(1): 23-32.

Caves, R. and Porter, M.E. (1977), From Entry Barriers to Mobility Barriers: Conjectural Decisions and Contrived Deterrence to New Competition, Quarterly Journal of Economics, 91: 241-261.

Charnes, A., Cooper, W.W., Lewin, A.Y. and Seiford, L.M. (1995), Data Envelopment Analysis: Theory, Methodology and Applications, Boston: Kluwer.

Charnes, A., Cooper, W.W. and Rhodes, E. (1978), Measuring the Efficiency of Decision Making Units, European Journal of Operations Research, 2(4): 429-444.

Coelli, T.J., Prasada, R. and Battese, G.E. (1998), An Introduction to Efficiency and Productivity Analysis, Boston: Kluwer.

Cooper, W.W., Seiford, L.M. and Tone, K. (2000), Data Envelopment Analysis, Boston: Kluwer.

Donaghy, K., McMahon, U. and McDowell, D. (1995), Yield Management: An Overview, International Journal of Hospitality Management, 14(2): 13391350.

Efron, B. (1979), Bootstrap Methods: Another Look at the Jackknife, Annals of Statistics, 7, 1-26.

Efron, B., Tibshirani, R.J. (1993), An Introduction to the Bootstrap, Chapman \& Hall Ed.

Färe, R.S. and Primont, D. (1995), Multi-Output Production and Duality: Theory and Applications, Boston, Kluwer Academic Publishers.

Färe, R.S., Grosskopf, S. and Lovell, C.A. (1994), Production Frontiers, Cambridge: Cambridge University Press.

Farrell, M.J. (1957), The Measurement of Productive Efficiency, Journal of the Royal Statistical Society, Series A, 120(3): 253-290.

Hwang, S.N. and Chang, T.Y. (2003), Using Data Envelopment Analysis to Measure Hotel Managerial Efficiency Change in Taiwan, Tourism Management, 24(2): 4.

Johns, N., Howcroft, B. and Drake, L. (1997), The Use of Data Envelopment Analysis to Monitor Hotel Productivity, Progress in Tourism and Hospitality Research, 3: 119-127.

Kneip, A., Park, B. and Simar, L. (1998), A Note on the Convergence of Nonparametric DEA Estimators for Production Efficiency Scores, Economic Theory, 14, 783-793.

Kneip, A., Simar, L. and Wilson, P.W. (2003), Asympotics for DEA Estimation in Non-Parametric Frontier Models, Discussion Paper, Institut de Statistique, Université Catolique de Louvain, Belgium.

Lovell, C.A.K. and Schmidt., P. (1988), A Comparison of Alternative Approaches to the Measurement of Productive Efficiency. In: Dogramaci, A., Färe, R. editors. Applications of Modern Production Theory: Efficiency and Productivity. Kluwer: 3-32.

Lovell, C.A.K. (1993), Production Frontiers and Productive Efficiency. In: Fried, H., Lovell, C.A.K. and Schmidt, S. editors. The Measurement of Productive Efficiency: Techniques and Applications. Oxford University Press: 3-67. 
Morey, R.C. and Dittman, D.A. (1995), Evaluating a Hotel GM's Performance: A Case Study in Benchmarking, Cornell Hotel Restaurant \& Administration Quarterly, 36(5): 30-35.

Narayan, P.K. (2005), The Structure of Tourist Expenditure in Fiji: Evidence from Unit Root Structural Break Tests, Applied Economics, 37: 1157-1161.

Porter, M.E. (1979), The Structure within Industries and Companies' Performance, The Review of Economics and Statistics, 61: 214-227.

Reynolds, D. (2003), Hospitality-Productivity Assessment using Data Envelopment Analysis, Cornell Hotel and Restaurant Administration Quarterly, 44(2): 130-137.

Rumelt, R. (1991), How Much Does Industry Matter? Strategic Management Journal, 12(2): 167-185.

Russell, R.R. (1990), Continuity of Measures of Technical Efficiency, Journal of Economic Theory, 51: 255-267.

Russell, R.R. (1997), Distance Functions in Consumer and Producer Theory. In: Index Number Theory: Essays in Honor of Sten Malmquist, Kluwer Academic Publishers: 7-90.

Santos, C. (2004), Framing Portugal: Representational Dynamics, Annals of Tourism Research, 31(1): 122-138.

Seiford, L. and Thrall, R. (1990), Recent Developments in DEA: The Mathematical Programming Approach to Frontier Analysis, Journal of Econometrics, 46: 7-38.

Simar, L. and Wilson, P.W. (2007), Estimation and Inference in Two-stage, Semiparametric Models of Production Processes, Journal of Econometrics, 136: 31-64.

Simar, L. and Wilson, P.W. (2000), Statistical Inference in Nonparametric Frontier Models: The State of the Art, Journal of Productivity Analysis, 13: 49-78.

Tavares, G. (2002), A Bibliography of Data Envelopment Analysis (1978-2001), RUTCOR Research Report, 1.

Teece, D., G. Pisano. and Shuen. A. (1997), Dynamic Capabilities and Strategic Management, Strategic Management Journal, 18(7): 509-533.

Thanassoulis, E. (2001), Introduction to the Theory and Application of Data Envelopment Analysis: A Foundation Text with Integrated Software, Dordrecht: Kluwer.

Wernerfelt, B. (1984), A Resource-Based View of the Firm, Strategic Management Journal, 5(2):171-180.

Wijeysinghe, B.S. (1993), Breakeven Occupancy for Hotel Operations, Management Accounting, 71 (2): 23-33. 
Table 1: Characteristics of the sample in 2004

\begin{tabular}{|c|c|c|c|c|c|}
\hline Nobs & Hotels & $\begin{array}{c}\text { Ranking in } \\
\text { the largest } \\
1000\end{array}$ & $\begin{array}{c}\text { Sales } \\
\text { (Millions €) }\end{array}$ & $\begin{array}{c}\text { Net } \\
\text { income } \\
\text { after } \\
\text { taxes }(€)\end{array}$ & $\begin{array}{l}\text { Number of } \\
\text { Employees }\end{array}$ \\
\hline 1 & Estoril Sol & 134 & 138,914 & 8,952 & 961 \\
\hline 2 & $\begin{array}{c}\text { Solverde-Investimentos } \\
\text { Túristicos da Costa Verde }\end{array}$ & 212 & 103,271 & 8,861 & 1,287 \\
\hline 3 & $\begin{array}{c}\text { M\&J Pestana - Soc. Turística } \\
\text { da Madeira }\end{array}$ & 411 & 52,605 & 11,828 & 662 \\
\hline 4 & $\begin{array}{c}\text { Vila Galé-Sociedade de } \\
\text { Empreendimentos Turísticos }\end{array}$ & 492 & 44,592 & 3,581 & 1,055 \\
\hline 5 & Enatur & 597 & 36,013 & $-1,229$ & 1,281 \\
\hline 6 & $\begin{array}{c}\text { Salvor-Soc. de Investimentos } \\
\text { Túristicos }\end{array}$ & 712 & 28,660 & 1,638 & 605 \\
\hline 7 & Sociedade Figueira Praia & 714 & 28,612 & 5,410 & 228 \\
\hline 8 & $\begin{array}{c}\text { Dom Pedro-Investimentos } \\
\text { Túristicos }\end{array}$ & 742 & 27,406 & 471 & 589 \\
\hline 9 & $\begin{array}{c}\text { Lusotur - Empreend. } \\
\text { Imobiliários e Turísticos }\end{array}$ & 747 & 27,235 & 2,152 & 211 \\
\hline 10 & $\begin{array}{c}\text { ITI - Invest. Turísticos da Ilha } \\
\text { da Madeira }\end{array}$ & 762 & 26,449 & 4,083 & 391 \\
\hline 11 & Portis - Hotéis Portugueses & 861 & 21,780 & 1,157 & 352 \\
\hline 12 & Hotéis Tivoli & 892 & 20,713 & 2,596 & 414 \\
\hline 13 & Hotel Ritz & 894 & 20,553 & -60 & 304 \\
\hline 14 & $\begin{array}{c}\text { Empreendimentos Turísticos } \\
\text { Savoy }\end{array}$ & 980 & 16,690 & 178 & 484 \\
\hline 15 & Hotéis Sheraton de Portugal & 997 & 14,786 & 300 & 230 \\
\hline
\end{tabular}


Table 2: Characteristics of the inputs and outputs

\begin{tabular}{|c|c|c|c|c|}
\hline \multicolumn{5}{|c|}{ Outputs } \\
\hline Variables & Units & Range & Mean & $\begin{array}{c}\text { Square } \\
\text { deviation }\end{array}$ \\
\hline Sales & $€$ & $\begin{array}{c}236.211,00- \\
2.300 .592,00\end{array}$ & $850.699,40$ & $491.143,16$ \\
\hline Number of guests & Number & $2452-23359$ & 16100 & 12476,37 \\
\hline \multicolumn{5}{|c|}{ Inputs } \\
\hline Variables & Units & Range & Mean & $\begin{array}{c}\text { Square } \\
\text { deviation }\end{array}$ \\
\hline Full-time workers & Number & $11-92$ & 56 & 21,36 \\
\hline Book value of property & $€$ & $\begin{array}{c}23.868,00- \\
7.768 .983,00\end{array}$ & $1.954 .570,00$ & 2.113.910,30 \\
\hline Operational costs & $€$ & $\begin{array}{c}984,00- \\
426.536,00\end{array}$ & $158.874,70$ & $95.476,50$ \\
\hline
\end{tabular}


Table 3: Literature survey of frontier models on Tourism

\begin{tabular}{|c|c|c|}
\hline Study & Method & Units \\
\hline Botti, Briec and Cliquet (2009) & DEA-CCR and BCC & $\begin{array}{l}15 \text { hotels chains } \\
\text { in France (1997) }\end{array}$ \\
\hline Barros and Dieke (2007) & $\begin{array}{c}\text { DEA two-stage procedure } \\
\text { (Malmquist and bootstrapped } \\
\text { tobit model) }\end{array}$ & $\begin{array}{l}25 \text { travel agencies } \\
\text { in Portugal } \\
(2000-2004)\end{array}$ \\
\hline Barros and Santos (2006) & DEA-allocative & $\begin{array}{l}15 \text { hotels in Portugal } \\
\text { (1998 to 2002) }\end{array}$ \\
\hline Barros (2005) & DEA-CCR and BCC & $\begin{array}{l}42 \text { Enatur hotels } \\
\text { in Portugal } \\
(1999-2001)\end{array}$ \\
\hline Barros and Alves (2004) & DEA-Malmquist & $\begin{array}{c}42 \text { Enatur hotels } \\
\text { in Portugal } \\
(1999-2001)\end{array}$ \\
\hline Hwang and Chang (2003) & $\begin{array}{c}\text { DEA-CCR, Superefficiency } \\
\text { and Malmquist }\end{array}$ & 45 hotels in Taiwan \\
\hline Reynolds (2003) & DEA CCR and BCC & 38 restaurants \\
\hline Brown and Ragsdale (2002) & $\begin{array}{l}\text { DEA-CCR and } \\
\text { cluster analysis }\end{array}$ & 46 US hotels \\
\hline Anderson, Fok and Scott (2000) & $\begin{array}{c}\text { DEA } \\
\text { (Technical and Allocative) }\end{array}$ & 48 hotels \\
\hline $\begin{array}{l}\text { Anderson, Fish, Xia and Michello } \\
\text { (1999) }\end{array}$ & $\begin{array}{l}\text { Stochastic Translog } \\
\text { Production Frontier }\end{array}$ & 48 hotels \\
\hline Anderson, Lewis and Parker (1999) & $\begin{array}{c}\text { DEA and } \\
\text { stochastic Frontier }\end{array}$ & $\begin{array}{l}31 \text { corporate } \\
\text { travel departments }\end{array}$ \\
\hline Johns, Howcroft and Drake (1997) & DEA & $\begin{array}{l}15 \text { UK hotels } \\
\text { over a 12-month period }\end{array}$ \\
\hline Bell and Morey (1995) & DEA & $\begin{array}{l}31 \text { units of corporate } \\
\text { travel departments }\end{array}$ \\
\hline Morey and Dittman (1995) & DEA & 54 hotels \\
\hline
\end{tabular}


Table 4: DEA efficiency scores for Portuguese hotels, 1998-2005

\begin{tabular}{|c|c|c|c|}
\hline Hotels designation & $\begin{array}{c}\text { Technical } \\
\text { Efficiency } \\
\text { CRS }\end{array}$ & $\begin{array}{c}\text { Technical } \\
\text { Efficiency } \\
\text { VRS }\end{array}$ & $\begin{array}{c}\text { Scale } \\
\text { Efficiency }\end{array}$ \\
\hline $\begin{array}{c}\text { Solverde-Investimentos Túristicos da } \\
\text { Costa Verde }\end{array}$ & 1.000 & 1.000 & 1.000 \\
\hline $\begin{array}{c}\text { Vila Galé-Sociedade de } \\
\text { Empreendimentos Turísticos }\end{array}$ & 1.000 & 1.000 & 1.000 \\
\hline Enatur & 1.000 & 1.000 & 1.000 \\
\hline M\&J Pestana-Soc. Turística da Madeira & 0.984 & 1.000 & 0.984 \\
\hline Estoril Sol & 0.956 & 1.000 & 0.956 \\
\hline $\begin{array}{c}\text { Salvor-Socied. de investimentos } \\
\text { Túristicos }\end{array}$ & 0.897 & 1.000 & 0.897 \\
\hline Dom Pedro-Investimentos Túristicos & 0.864 & 0.997 & 0.867 \\
\hline Hotéis Tivoli & 0.924 & 0.944 & 0.978 \\
\hline $\begin{array}{c}\text { ITI-Invest. Turísticos da Ilha da } \\
\text { Madeira }\end{array}$ & 0.726 & 0.990 & 0.733 \\
\hline Hotel Ritz & 0.969 & 0.984 & 0.985 \\
\hline $\begin{array}{c}\text { Lusotur-Empreend. Imobiliários e } \\
\text { Turísticos }\end{array}$ & 0.879 & 0.954 & 0.921 \\
\hline Empreendimentos Turísticos Savoy & 0.799 & 0.951 & 0.840 \\
\hline Portis-Hotéis Portugueses & 0.905 & 0.937 & 0.966 \\
\hline Sociedade Figueira Praia & 0.919 & 0.921 & 0.997 \\
\hline Hotéis Sheraton de Portugal & 0.830 & 0.912 & 0.910 \\
\hline Mean & 0.910 & 0.972 & 0.935 \\
\hline Median & 0.919 & 0.990 & 0.966 \\
\hline Std. Dev & 0.080 & 0.032 & 0.076 \\
\hline
\end{tabular}


Table 5: Truncated bootstrapped second-stage regression

(dependent variable: CCR index)

\begin{tabular}{|c|c|c|c|}
\hline Variable & Model 1 & Model 2 & Model 3 \\
\hline Constant & $-1.16^{*}$ & $-1.10^{*}$ & $-1.16^{*}$ \\
\hline Trend & $0.11^{*}$ & $0.09^{*}$ & $0.192^{*}$ \\
\hline Square trend & $-0.03^{*}$ & $-0.07^{*}$ & -0.071 \\
\hline Quoted & $0.03^{*}$ & 0.02 & $0.042^{*}$ \\
\hline M\&A & $0.03^{*}$ & $0.05^{*}$ & $0.025^{*}$ \\
\hline Group & $0.16^{* * *}$ & $0.13^{*}$ & $0.15^{*}$ \\
\hline International & 0.01 & - & $-0.06^{* * *}$ \\
\hline Variance & $0.06^{* * *}$ & $0.07^{*}$ & 1000 \\
\hline $\begin{array}{c}\text { Total number of } \\
\text { observations }\end{array}$ & 1000 & 1000 & \\
\hline
\end{tabular}

